\title{
ANALISIS KINERJA KARYAWAN BERDASARKAN KOMUNIKASI, STRES KERJA,KONFLIK KERJA PT. SUMBAR ANDALAS KENCANA POM MUARA TIMPEH KABUPATEN DHARMASRAYA
}

\author{
Neni Sri Wahyuni Nengsih ${ }^{1)}$ Desi Permata Sari ${ }^{2)}$ Agung Ramadhanu ${ }^{3)}$
}

${ }^{1}$ Fakultas Ekonomi dan Bisnis, Universitas Putra Indonesia YPTK Nenisriwahyuni nengsi@upiyptk.ac.id

${ }^{2}$ Fakultas Ekonomi dan Bisnis, Universitas Putra Indonesia YPTK Desipermatasari735@gmail.com

\author{
${ }^{3}$ Fakultas Ilmu Komputer, Universitas Putra Indonesia YPTK \\ Agung_ramadhanu@upiyptk.ac.id
}

\begin{abstract}
ABSTRAK
Penelitian ini bertujuan untuk mengetahui dan menganalisis analisis kinerja karyawan berdasarkan komunikasi, stres kerja dan konflik kerja pada PT. Sumbar Andalas Kencana POM Muara Timpeh Kabupaten Dharmasraya, baik secara parsial maupun secara simultan.

Dari hasil analisis regresi didapat Hasil uji hipotesis secara parsial diperoleh bahwa variabel komunikasi, Stress kerja, dan konflik kerja berpengaruh positif dan signifikan terhadap kinerja karyawan. Hasil uji hipotesis secara simultan juga diperoleh variabel komunikasi, Stress kerja, dan konflik kerja berpengaruh positif dan signifikan terhadap kinerja karyawan bagian produksi pada PT. Sumbar Andalas Kencana POM Muara Timpeh Kabupaten Dharmasraya. Kontribusi ketiga variabel bebas tersebut di atas terhadap kinerja karyawan adalah sebesar 45,2\% sedangkan sisanya 54,8\% dari variabel lain yang tidak diteliti. Secara parsial terbukti komunikasi memiliki pengaruh yang paling dominan.
\end{abstract}

Kata Kunci: Komunikasi, Stres Kerja, Dan Konflik kerja, Kinerja Karyawan.

\section{PENDAHULUAN}

\subsection{Latar Belakang}

Sumber daya manusia (SDM) memegang peranan yang sangat dominan dalam kegiatan perusahaan. Berhasil atau tidaknya perusahaan dalam mencapai tujuan sangat tergantung pada kemampuan SDM atau karyawannya dalam menjalankan tugas-tugas yang diberikan sehingga karyawan dituntut untuk selalu mampu mengembangkan diri secara proaktif dalam suatu perusahaan. SDM yang diperlukan saat ini adalah SDM yang memiliki kinerja

\section{Mangkunegara}

(2014:9), menyatakan kinerja karyawan adalah hasil kerja secara kualitas dan kuantitas yang dicapai oleh seseorang karyawan dalam melaksanakan tugasnya sesuai dengan tanggung jawab yang diberikan kepadanya. Kinerja karyawan yang optimal dapat terlihat baik dari kualitas maupun kuantitas yang sangat diperlukan untuk mendukung tercapainya tujuan perusahaan.

Pengelolaan Sumber Daya Manusia bukanlah mudah, karena mereka mempunyai keinginan, pikiran, perasaan, status latar belakang yang dibawa ke dalam organisasi memungkinkan terjadinya miskomunikasi, konflik, dan kadangkalanya akibat konflik terjadinya stres kerja.

Wood (2012:3), menyatakan bahwa komunikasi adalah sebuah proses sistemais dimana orang berinteraksi dengan dan melalui simbol untuk menciptakan dan menafsirkan makna.

\section{Mangkunegara}

(2014:179), mengemukakan bahwa stres kerja adalah perasaan yang menekan atau merasa 
tertekan yang dialami karyawan dalam menghadapi pekerjaan.

Menurut Marwansyah (2012:302), konflik adalah ketidaksesuaian atau perbedaan antara tujuan-tujuan yang ingin dicapai atau metode yang digunakan untuk mencapai tujuan tersebut.

PT. Sumbar Andalas Kencana POM Muara Timpeh merupakan salah satu perusahaan yang bergerak dibidang perkebunan dan pengelolahan kelapa sawit yang hasil akhirnya berupa minyak kelapa sawit atau CPO (Crude Palm Oil). Sebagaimana layaknya sebuah organisasi, PT. Sumbar Andalas Kencana POM Muara Timpeh selalu berusaha meningkatkan kualitas sumber daya manusianya.Untuk itu kualitas karyawan dan segala keperluan yang mendukung kelancaran pekerjaan dan lingkungan kerja harus terus ditingkatkan. Berikut ini adalah gambaran kinerja karyawan PT. Sumbar Andalas Kencana POM Muara Timpeh pada lima tahun terakhir yang terlihat pada tabel berikut ini :

Tabel 1.1

Target dan Realisasi Produksi CPO (Crude Palm Oil) pada

PT. Sumbar Andalas Kencana POM Muara Timpeh Tahun 2012-2016

\begin{tabular}{|l|l|l|l|}
\hline Tahun & $\begin{array}{l}\text { Target } \\
\text { poduksi } \\
\text { (Kg) }\end{array}$ & $\begin{array}{l}\text { Realisasi } \\
\text { Produksi } \\
\text { (Kg) }\end{array}$ & $\begin{array}{l}\text { Persentase } \\
\text { (\%) } \\
\text { Pencapaia } \\
\text { n }\end{array}$ \\
\hline 2012 & 45.144 .000 & 44.654 .391 & 98,92 \\
\hline 2013 & 48.710 .000 & 46.297 .012 & 95,05 \\
\hline 2014 & 51.052 .000 & 49.535 .567 & 97,03 \\
\hline 2015 & 70.632 .000 & 67.120 .431 & 95,03 \\
\hline 2016 & 70.732 .000 & 64.874 .371 & 91,72 \\
\hline
\end{tabular}

Sumber: PT. Sumbar Andalas Kencana Muara Timpeh

Dari Tabel 1.1 terlihat capaian target produksi CPO (Crude Palm Oil) berfluktuasi. Pada tahun 2012 capaian produksi sebesar 98,92\%, tahun 2013 capaian target produksi perusahaan mengalami penurunan $95,05 \%$. Tahun
2014 capaian target produksi sebesar $97,03 \%$, lalu menurun pada tahun 2015 sebesar 95,03\%. Pada tahun 2016 capaian target produksi kembali mengalami penurunan sebesar $91,72 \%$ dari target produksi CPO perusahaan $100 \%$.

Dari hal tersebut di atas, terindikasi kinerja karyawan belum optimal disinyalir disebabkan oleh komunikasi, stres kerja, dan konflik kerja.Berdasarkan data di atas, maka dipandang perlu dilakukan penelitian dengan judul "Analisis Kinerja Karyawan Berdasarkan Komunikasi, Stres Kerja dan Konflik Kerja Pada PT. Sumbar Andalas Kencana

\subsection{Landasan Teori}

\subsubsection{Kinerja Karyawan}

Menurut Rivai (2013:604), kinerja merupakan suatu istilah secara umum yang digunakan sebagian atau seluruh tindakan atau aktivitas dari suatu organisasi pada suatu periode dengan suatu referensi pada sejumlah standar seperti biaya masa lalu yang diproyeksikan dengan dasar efisiensi, pertanggungjawaban atau akuntabilitas manajemen dan semacamnya.

\section{Menurut Moeheriono (2014:95),} kinerja merupakan gambaran mengenai tingkat pencapaian pelaksanaan suatu program kegiatan atau kebijakan dalam mewujudkan sasaran, tujuan, visi dan misi organisasi yang dituangkan melalui perencanaan strategis suatu organisasi.

\subsubsection{Komunikasi}

Menurut Liliweri (2014:359), komunikasi merupakan rangkaian proses pengalihan informasi dari satu orang kepada orang lain dengan maksud tertentu.

Sedangkan menurut Sinambela (2016:511), komunikasi adalah suatu proses pembentukan, penyampaian, penerimaan, dan pengolahan pesan yang terjadi di dalam diri seseorang dan/atau diantara dua atau lebih dengan tujuan tertentu.

\subsubsection{Stres Kerja}

Menurut Mangkunegara (2014:179), mengemukakan bahwa stres kerja adalah 
perasaan yang menekan atau merasa tertekan yang dialami karyawan dalam menghadapi pekerjaan.

Sedangkan menurut Sunyoto (2012:61), stres mempunyai arti berbedabeda bagi masing-masing individu. Kemampuan setiap orang beraneka ragam dalam mengatasi jumlah, intensitas, jenis dan lamanya stres.Orang lebih mudah membicarakan ketegangan daripada stres.Stres merupakan sesuatu yang menyangkut interaksi antara individu dan lingkungan yaitu interaksi antara stimulasi dan respons, dengan demikian stres kerja (job stress) adalah konsekuensi setiap tindakan dan situasi lingkungan yang menimbulkan tuntutan psikologis dan fisik secara berlebihan pada seseorang. Stres bukanlah sesuatu yang aneh atau yang tidak berkaitan dengan keadaan normal yang terjadi pada orang yang normal atau tidak semua stres bersifat negatif. Stres kerja yang dialami oleh karyawan akibat lingkungan yang dihadapinya akan mempengaruhi kinerja dan kepuasaan kerjanya.

\subsubsection{Konflik Kerja Menurut}

Marwansyah (2012:302), konflik adalah ketidaksesuaian atau perbedaan antara tujuan-tujuan yang ingin dicapai atau metode yang digunakan untuk mencapai tujuan tersebut.

Menurut Surbakti (2012:133), mendefinisikan konflik dari sisi psikologi adalah ketegangan atau stres yang terjadi karena pemuasan kebutuhan dihadapkan kepada dua alternatif yang sama menarik atau tidak menarik.

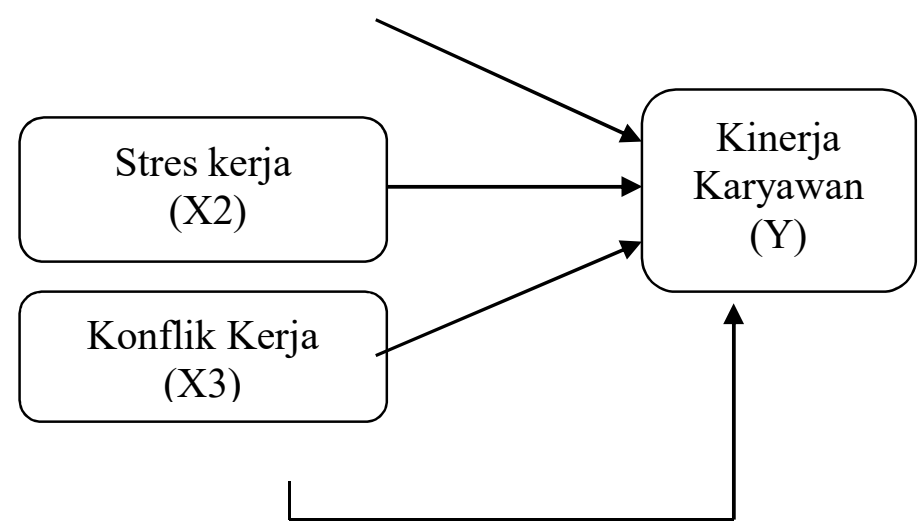

2.3 Hipotesis

Menurut Sugiyono (2013:64), hipotesis merupakan jawaban sementara terhadap rumusan masalah penelitian. Hipostesis dari kerangka pemikiran diatas adalah:

1. Komunikasi berpengaruh dan signifikan terhadap kinerja karyawan PT. Sumbar Andalas Kencana POM Muara Timpeh Kabupaten Dharmasraya.

2. Stres kerja berpengaruh dan signifikan terhadap kinerja karyawan PT. Sumbar Andalas Kencana POM Muara Timpeh Kabupaten Dharmasraya.

3. Konflik kerja berpengaruh dan signifikan terhadap kinerja karyawan PT. Sumbar Andalas Kencana POM Muara Timpeh Kabupaten Dharmasraya.

4. Komunikasi, stres kerja, dan konflik kerja berpengaruh signifikan terhadap kinerja karyawan PT. Sumbar Andalas Kencana POM Muara Timpeh Kabupaten Dharmasraya.

\section{METODE PENELITIAN}

\subsection{Objek Penelitian}

Objek penelitian ini adalah analisis kinerja karyawan berdasarkan komunikasi, stres kerja, dan konflik kerja. Penelitian ini akan dilakukan pada PT. Sumbar Andalas Kencana POM Muara Timpeh Kabupaten Dharmasraya

\subsection{Desajn Penelitian}


Desain penelitian yang digunakan dalam penelitian ini adalah penelitian deskriptif dan asosiatif. Menurut Sugiyono (2013:11), metode penelitian deskriptif adalah penelitian yang dilakukan untuk mengetahui nilai variabel mandiri, baik satu variabel atau lebih (independen) tanpa membuat perbandingan, atau menghubungkan dengan variabel yang lain.

Metode penelitian asosiatif menurut Sugiyono (2013:11) adalah penelitian yang bertujuan untuk mengetahui pengaruh ataupun juga hubungan antara dua variabel atau lebih.Dalam penelitian ini, metode penelitian deskriptif dan asosiatif digunakan untuk mengetahui pengaruh komunikasi, stres kerja, dan konflik kerja berpengaruh signifikan terhadap kinerja karyawan PT. Sumbar Andalas Kencana POM Muara Timpeh Kabupaten Dharmasraya.

\subsection{Populasi dan Sampel}

\subsubsection{Populasi}

Menurut Sugiyono (2013:115), populasi adalah wilayah generalisasi terdiri dari objek/subjek yang mempunyai kualitas dan karakteristik tertentu yang ditetapkan oleh peneliti untuk dipelajari kemudian ditarik kesimpulannya. Populasi dalam penelitian ini adalah seluruh karyawan PT. Sumbar Andalas Kencana POM Muara Timpeh Kabupaten Dharmasraya yang berjumlah 97 orang.

\subsubsection{Sampel}

Menurut Sugiyono (2013:116), sampel adalah bagian dari jumlah dan karakteristik yang dimiliki oleh populasi tersebut. Bila populasi besar, dan peneliti dan tidak mungkin mempelajari semua yang ada pada populasi, misalnya karena keterbatasan dana, tenaga, dan waktu, maka peneliti dapat menggunakan sampel yang diambil dari populasi itu. Teknik sampling yang digunakan dalam penelitian ini adalah Nonprobality Sampling. Menurut Sugiyono (2013:120), Nonprobality Sampling adalah teknik pengambilan sampel yang tidak memberikan peluang atau kesempatan sama bagi setiap unsur atau anggota populasi untuk dipilih menjadi sampel. Teknik sampel dalam penelitian ini menggunakan sampel jenuh yaitu teknik penentuan sampel bila semua anggota populasi digunakan sebagai sampel, hal ini sering dilakukan bila jumlah populasi relatif kecil, kurang dari 30 orang, atau penelitian yang ingin membuat generalisasi dengan kesalahan yang sangat kecil. Jadi jumlah sampel dalam penelitian ini adalah 97 orang karyawan PT. Sumbar Andalas Kencana POM Muara Timpeh Kabupaten Dharmasraya.

\subsection{Uji Instrumen Penelitian}

Untuk menguji instrumen yang digunakan dalam penelitian ini, maka digunakan alat uji validitas dan reliabilitas, yaitu:

\section{Uji Validitas Instrumen}

Menurut Ghozali (2013:52) uji validitas digunakan untuk mengukur sahatau valid tidaknya suatu kuesioner.Dalam hal ini koefisien korelasi yang nilai signifikannya lebih kecil dari $5 \%$ (level of significance) menunjukkan bahwa pernyataan-pernyataan tersebut sudah sahih sebagai pembentuk indikator. Dasar analisis yang digunakan untuk pengujian validitas sebagai berikut (Ghozali,2013:53) yaitu:

a. Jika $r$ hitung $>r$ tabel maka butir atau variabel tersebut valid.

b. Jika $r$ hitung $<r$ tabel maka butir atau variabel tersebut tidak valid.

\section{Uji Reliabilitas Instrumen}

Ghozali (2013:47) mengatakan reliabilitas adalah suatu angka yang menunjukkan konsistensi suatu alat ukur didalam mengukur objek yang sama. Reliabilitas suatu konstruk variable dikatakan baik jika memiliki nilai Alpha Cronbach's $>0,60$

Dalam penelitian ini uji validitas dan uji reliabilitas dihitung dengan 
menggunakanprogram IBM SPSS Versi 21.

\subsection{Pengujian Hipotesis}

Pengujian hipotesis dalam penelitian ini uji $\mathrm{t}$ dan uji $\mathrm{F}$ dengan menggunakan bantuan program IBM SPSS Versi 21.

\section{Uji t}

Menurut Ghozali (2013:98), uji t adalah seberapa jauh pengaruh satu variable independen secara individual dalam menerangkan variasi variabel dependen. Dalam penelitian ini peneliti menguji pengaruh komunikasi, stres kerja dan konflik kerja terhadap kinerja karyawan.

\section{Uji F}

Menurut Ghozali (2013:98), uji F pada dasarnya menunjukkan apakah semua variabel independen yang dimasukkan dalam model mempunyai pengaruh secara simultan terhadap variabel dependen.

\section{HASIL DAN PEMBAHASAN}

\subsection{Analisis Korelasi dan Regresi Linear Berganda}

\subsubsection{Analisis Korelasi}

Analisis korelasi bertujuan untuk melihat pengaruh komunikasi, stres kerja, konflik kerja terhadap kinerja karyawan. Berikut hasil korelasi berganda pada tabel 4.18, dibawah ini:

$$
\begin{aligned}
& \text { Tabel } 4.18
\end{aligned}
$$

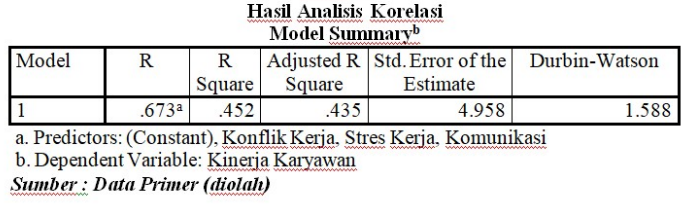

Pada Tabel 4.18 dapat diketahui nilai keeratan hubungan komunikasi, stress kerja, konfluk kerja terhadap kinerja karyawan terhadap sebesar 0,67 , ini berarti ketiga variabel tersebut memiliki pengaruh yang sangat kuat dalam mempengaruhi kinerja karyawan PT. SAK POM Muara Timpeh Kabupaten Dharmasraya.

\subsubsection{Analisa Regresi Linear Berganda}

Analisis regresi linear berganda adalah analisis untuk mengukur besarnya pengaruh antara dua atau lebih variabel independen terhadap satu variabel dependen dan memprediksi variabel dependen dengan menggunakan variabel independen.Analisis regresi berganda dilakukan untuk melihat pengaruh variabel (komunikasi, stress kerja, konflik kerja terhadap kinerja karyawan).

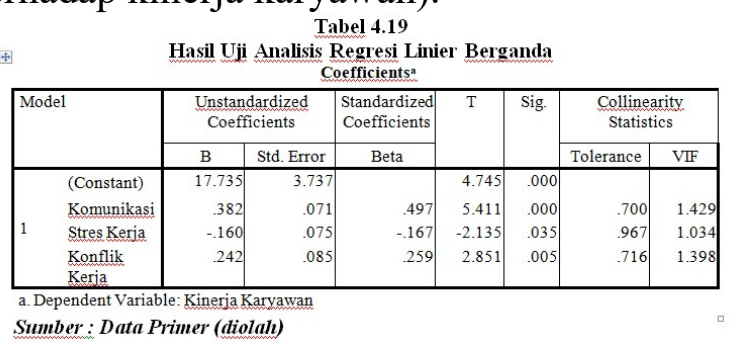

Berdasarkan tabel di atas maka dapat disimpulkan sebagai berikut :

1. Pengaruh Komunikasi terhadap Kinerja Karyawan

Nilai t hitung $>\mathrm{t}$ tabel $(5.411>1,661$ dengan tingkat siginifikan $(0,000<$ $0,05)$, artinya secara parsial ada pengaruh yang positif dan signifikan antara komunikasi terhadap kinerja karyawan, dengan demikian $\mathrm{Ha}$ diterima dan Ho ditolak. Artinya semakin tinggi komunikasi, maka semakin tinggi kinerja karyawan, sebaliknya semakin rendah komunikasi maka kinerja karyawan menurun.

2. Pengaruh Stress Kerja terhadap Kinerja Karyawan

Nilai $\mathrm{t}$ hitung $<\mathrm{t}$ tabel $(-2.135<$ 1,661) dengan tingkat siginifikan $(0,035<0,05)$, artinya tidak ada pengaruh yang positif dan signifikan antara stress kerja terhadap kinerja karyawan,dengan demikian Ho diterima dan $\mathrm{Ha}$ ditolak. Artinya, semakin rendah stres kerja, maka semakin tinggi kinerja karyawan, sebaliknya semakin tinggi stres kerja maka semakin rendah kinerja karyawan. 


\section{Pengaruh Konflik Kerja terhadap Kinerja Karyawan}

Nilai thitung $>\mathrm{t}$ tabel $(2.851>1,665)$ dengan tingkat siginifikan $(0,005<$ $0,05)$, artinya secara parsial ada pengaruh yang positif dan signifikan antara konflik kerja terhadap kinerja karyawan, dengan demikian $\mathrm{Ha}$ diterima dan Ho ditolak. Artinya semakin tinggi konflik kerja, maka semakin rendah kinerja karyawan, sebaliknya semakin rendah konflik kerja maka kinerja karyawan semakin tinggi.

\begin{tabular}{|c|c|c|c|c|c|c|}
\hline \multicolumn{7}{|c|}{$\begin{array}{c}\text { Tabel } 4.21 \\
\text { Hasil Pengujian F } \\
\underset{\text { ANOVA }}{ }\end{array}$} \\
\hline \multicolumn{2}{|c|}{ Model } & $\begin{array}{l}\text { Sum of } \\
\text { Squares }\end{array}$ & $\mathrm{Df}$ & $\begin{array}{c}\text { Mean } \\
\text { Square }\end{array}$ & $\bar{F}$ & Sig. \\
\hline \multirow{3}{*}{1} & Regression & 1887.822 & 3 & 629.274 & 25.597 & $.000^{2}$ \\
\hline & Residual & 2286.343 & 93 & 24.584 & & \\
\hline & Total & 4174.165 & 96 & & & \\
\hline
\end{tabular}

Hasil uji F digunakan untuk mengetahui apakah variabel independen berpengaruh terhadap variabel dependen secara simultan. Pada tabel 4.21 didapat $F_{\text {hitung }}>F_{\text {tabel }}(25,597>3,09)$ dan nilai signifikan kinerja karyawan sebesar 0,000 sedangkan tingkat kepercayaan yang digunakan adalah 5\% (0,05). Dengan demikian nilai signifikansi sebesar $0,000<$ 0,05 , maka dapat disimpulkan bahwa variabel komunikasi, stress kerja, konflik kerja secara bersama-sama dapat mempengaruhi kinerja karyawan.

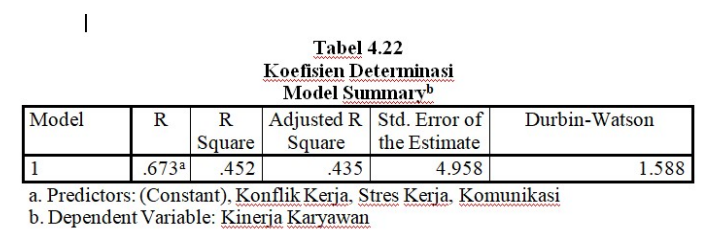

Berdasarkan Tabel 4.22, Adjusted R Square sebesar 0,435 artinya sumbangan komunikasi, stress kerja, konflik kerja terhadap kinerja karyawan sebesar 43,5\% sedangkan sisanya $56,5 \%$ dipengaruhi oleh faktor lain seperti lingkungan kerja, kepuasan kerja, disiplin kerja, pengawasan pimpinan dan lain sebagainya.

\section{SIMPULAN}

Penelitian ini bertujuan untuk menguji secara empiris pengaruh variabel independen yaitu pengaruh komunikasi, stress kerja, konflik kerja terhadap variabel dependen kinerja karyawan PT. SAK POM Muara Timpeh Kabupaten Dharmasraya.Penelitian ini dilakukan terhadap 97 responden PT. SAK POM Muara Timpeh Kabupaten Dharmasraya. Dengan menggunakan alat uji regresi linier berganda ditemukan hasil uji hipotesis sebagai berikut:

1. Terdapat pengaruh positif dan signifikan Komuninikasi terhadap kinerja karyawan PT. SAK POM Muara Timpeh Kabupaten Dharmasraya.

2. Tidak berpengaruh positif dan signifikan stres kerja terhadap kinerja karyawan PT. SAK POM Muara Timpeh Kabupaten Dharmasraya..

3. Terdapat pengaruh positif dan signifikan konflik kerja terhadap kinerja karyawan PT. SAK POM Muara Timpeh Kabupaten Dharmasraya.

4. Terdapat pengaruh positif dan signifikan komunikasi, stress kerja, konflik kerja terhadap kinerja karyawan Terdapat pengaruh positif dan signifikan Komuninikasi terhadap kinerja karyawan PT. SAK POM Muara Timpeh Kabupaten Dharmasraya., dimana $\mathrm{F}_{\text {hitung }}>\mathrm{F}_{\text {tabel }}$ $(25,597>3,09)$ dengan nilai signifikan $0,000<0,05$.

\section{DAFTAR PUSTAKA}

Ghozali, Imam. 2011. "Aplikasi Analisis Multivariate Dengan Program SPSS". Semarang: Badan Penerbit Universitas Diponegoro.

Ghozali, Imam. 2013. Aplikasi Analisis Multivariate dengan Program SPSS. Edisi Ketujuh. Semarang : Badan Penerbit Universitas Diponegoro. 
Liliweri Alo, (komunikasi serba ada serba makna),Jakarta: kencana prenada media group, 2011

Mangkunegara, Anwar, P., 2014. Manajemen Sumber Daya Manusia Perusahaan. Bandung: PT. Remaja Rosdakarya.

Marwansyah. 2012. Manajemen Sumber Daya Manusia. Bandung: Alfabeta.

Moeheriono. 2014. Pengukuran Kinerja Berbasis Kompetensi, Edisi Revisi.Jakarta: Rajawali Pers.

Mulyana, Deddy. Ilmu Komunikasi: Suatu Pengantar. Cetakan ke 18. Bandung: PT. Remaja Rosdakarya, 2014

Rivai, Veithzal dan Ella Sagala.2013. Manajemen Sumber Daya Manusia untuk Perusahaan. Jakarta: Rajawali Pers.

Sinambela, Lijan Poltak. 2016. Manajemen Sumber Daya Manusia. Jakarta: PT Bumi Aksara

Surbakti, Theresa Adelina Victoria.2012. Pengaruh
Perusahaan dan Reformasi

Perpajakan Terhadap

Penghindaran Pajak di

Perusahaan Industri Manufaktur yang Terdaftar di Bursa Efek Indonesia Tahun 2008-2010. Skripsi Jurnal Akuntansi Fakultas Ekonomi Universitas Indonesia, Jakarta

Sugiyono. 2013. Metode Penelitian Bisnis. Bandung : Alfabeta.

Suwatno dan Donni Juni Priansa, 2012.Manajemen Sumber Daya Manusia. Bandung: Alfabeta.

Sunyoto, D. 2012. Manajemen Sumber Daya Manusia. Yogyakarta : CAPS

Wibowo. 2013. Perilaku dalam Organisasi. Jakarta: PT. Raja Grafindo Persada.

Wood, Julia T. 2013.Komunikasi Interpersonal Interaksi Keseharian, Edisi 6.Jakarta : Salemba Humanika. 